\title{
«DET ER HELT VILDT!» - OM LÆSESTRATEGIER OG RECEPTION AF EN UDSTILLING
}

\section{Bruno Ingemann}

En udstilling kommunikerer gennem genstand, ord og billeder. En udstilling har en fortalling. Men hvilken fortalling skaber den besøgende? Hvordan skaber man betydning $i$ udstillingens kaos? Hvilke vardier synes den besøgende er vigtig? Hvorfor adskiller disse vardier sig fra hvad museet synes er vigtigt? Skal man opdrage de besøgende? Gennem beskrivelse og analyse fokuseres $p a ̊$ den individuelle besøgendes reception af en udstilling på Københavns Bymuseum. Og artiklen er samtidig en prosentation af en helt ny metode til indsamling af empiri ved museumsbesøget.

En udstilling kan ses som en konglomerat af et utal af fysiske ting: autentiske genstande, tekster, fotografier, modeller, tegninger, planer, lyd, lugte, video, lys/dias, multimedier - og så det taktile: rum og overflader.

Man kan se udstillingen som en historie hvor alle disse elementer indgår i den samlede fortælling.

Ud fra en tegn- og receptionsteoretisk synsvinkel er det muligt at analysere den samlede udstilling for at finde ud af hvilke betydningspotentialer der ligger i udstillingen set med en besøgendes blik. Den besøgende tager ikke nødvendigvis udgangspunkt i museet eller museumsinspektørens intensjoner, men i sine egne muligheter for at passe museets udstilling ind $\mathrm{i}$ sine interesser. Formålet med en sådan analyse er at undersøge og argumen- tere for en mangfoldighed af betydninger der ligger i de autentiske genstande og i de elementer der modarbejder eller støtter genstandenes fortælling og den overordnede fortælling.

Hvordan pakkes genstandenes historier ud? Hvordan påvirker relationen mellem genstande og genstande hinanden? Hvordan indgår andre elementer - fx tekster i relationen til genstandene? Hvilke myter ligger som grundlag for fortællingens dele - eller hvilke myter giver udstillingen mulighed for at den besøgende lægger ind i fortællingens dele?

Det overordnede kodeord er Relationer. Relationer mellem genstand og virkelighed; relationer mellem genstand og genstand; relationer mellem genstand og tekst; Og den allervigtigste relation: mellem genstand og den besøgende. 
156 I denne søgen efter de betydningspotentialer udstillingen har, er det netop muligheder og mangfoldighed der er afgørende set fra den besøgendes synsvinkel.

Men der er meget stor afstand mellem de mulige betydningspotentialer og de realiserede betydninger. En kendte receptionsteoretiker som Stanley Fish er meget kategorisk: Teksten findes ikke. ${ }^{1}$

Hvis vi lige et øjeblik opfatter begrebet tekst som hele det konglomerat af elementer jeg tidligere har skrevet om, så mener Stanley Fish altså at der slet ikke findes en tekst. Han synspunkt er at der først findes en tekst hvis læseren aktualiserer den fysiske tekst. Det er altså læseren der skaber teksten og kun den del af teksten som aktualiseres bliver til læserens tekst.

Stanly Fish mener altså at teksten skabes af den individuelle læser.

Edwina Taborsky følger sådan set dette synspunkt men afviger på et afgørende punkt nemlig at teksten skabes gennem en social praksis. Det betyder at det først er gennem samtalen mellem mennesker om den fysiske tekst, at denne tekst aktualiseres og dermed bliver synlig og bevidst. ${ }^{2}$

Hermed har vi bevæget os fra det receptionsteoretiske: betydningspotentiale over til det receptionsempiriske: realisering af potentialer.

Hvordan er det muligt at indfange og analysere den konkrete realisering af potentialerne $\mathrm{i}$ en udstilling? ${ }^{3}$

Man kan bruge forskellige metoder der er tættere eller fjernere på den konkrete oplevelse:

Under museumsoplevelsen:

- iagttagelse og registrering af den besøgendes vandring $i$ udstillingen
Umiddelbart efter museumsoplevelsen:

- spørgeskema

- individuelle interviews

- fokusgruppe interviews

Lange efter museumsoplevelsen:

- individuelle og gruppe interviews ét til to år efter besøget på museet fx som Falk \& Dierking (1992) overbevisende demonstrerer i deres bog hvor de udvikler teorien om de tre kontekster: den personlige, den fysiske og den sociale kontekst.

For de fleste af metoderne gælder det om at i-tale-sætte oplevelsen. Dvs. at formulere den historie eller de historier som besøget på museet er mulig for den besøgende at genkalde og tale om.

Den største forskel mellem metoderne ligger $\mathrm{i}$ om man enten har en kvantitativ eller kvalitativ tilgang til undersøgelsen. Den kvantitative vil oftest lægge vægt på spørgeskemaet og fordelen er at man kan få mange klare svar på enkle spørgsmål som det er muligt at kvantificere og behandle statistisk. Den kvalitative tilgang vil lægge vægt på relativ få informanter og til gengæld at kunne forfølge den individuelle historie som informanten konstruerer gennem interviewet. Det store problem med de kvalitative tilgang er af finde teorier og metoder der gør det muligt at skabe mening i de ofte fragmentariske og selvmodsigende udsagn informanterne producerer gennem interviewet.

\section{THE MUSEUM EXPERIENCE PROJECT}

Mit projekt har som udgangspunkt at museet kan ses som en organiseret virkelighed. Ud af virkelighedens kaos er der skabt en struktur og en slags fortælling af museets inspektører. For den besøgende er 
det stadigvæk temmelig kaotisk fordi den faglige struktur ikke stemmer overens med den besøgendes struktur; fordi genstandens historie ikke er den besøgendes historie og skal pakkes ud; fordi museet præsenterer én mulig læsestrategi måske sammensat af tid og rum, kronologi, årsag/virkning, udvikling, fremskridt...; fordi den besøgende har andre læsestrategier som hun må anvende når museet ikke tilbyder nogen anvendelig læsestrategi; fordi...

Min erkendelsesinteresse er: Hvad og hvordan oplever den besøgende udstillingen på museet - og hvordan skaber den besøgende betydning.

Det er en kendt metode at iagttage og registrere en besøgendes vandring rundt $\mathrm{i}$ udstillingen og bruge grundplaner og ur til at fastslå, hvor og hvor længe den besøgende står bestemte steder i udstillingen. Denne metode kan bruges til at lave statistik på hvor de "hotte» punkter er i en udstilling. Man kan også gå det skridt videre og lave individuelle interviews med den besøgende og bruge registreringen til at snakke ud fra for at få $\mathrm{i}$-tale-sat de fysiske bevægelser.

Jeg havde en undren og en nysgerrighed efter at finde ud af om det var muligt at komme tættere på den besøgendes oplevelser. At kunne flytte opmærksomheden tættere på det som den besøgende så på og dermed havde mulighed for at realisere.

Et udgangspunkt var den forskningstradition hvor man med avanceret video- og computerudstyr forsøger at registrere øjenbevægelser hen over billeder eller avissider. Eye-tracking forsøger altså at finde øjnenes spor hen over avissiden. Hvor fokuserer øjet og aflæser billedeelementer og tekstdele? Hvordan bevæger øjet sig 157 hen over avissiden? Er der særlige forhold der fastholder øjet? Farver, størrelser, placering? Det er den slags spørgsmål man kan få svar på inden for den forskning. Men hvad man ikke kan svare på er hvorfor øjnene bevæges på den måde og især hvilke betydninger læseren tillægger de enkelte informationer og hvordan den nye information forbinder sig med den viden og de oplevelser som informanten allerede har.

Et andet udgangspunkt var mit arbejde med en kvalitetsundersøgelse af hvordan læsere tilskriver værdier til pressefotografier gennem brugen af en række læsestrategier. ${ }^{4}$

Disse overvejelser førte til at jeg besluttede mig for at konstruere et udstyr der kunne bruges til at registrere hvordan de besøgende vandrede rundt $\mathrm{i}$ udstillingen og hvad det var de egentlig så på for at skabe det empiriske grundlag for analyser af den besøgendes værdier.

Jeg fik konstrueret en kasket hvorpå der er anbragt et meget lille videokamera. Denne kasket bærer den besøgende på hovedet og hvor den besøgendes hoved bevæger sig, bevæger videokameraet sig også.

Den besøgende har også en Fjeldräven på ryggen eller $i$ hånden. I Fjeldräven er der placeret en lille videorecorder som optager lyd og billeder og diverse strømforsyninger til kameraet og recorderen.

Informanten skal gå rundt i udstillingen sammen med en ven eller veninde, fordi jeg ser besøget på museet, som primært en social begivenhed. Det er den ene grund. Den anden er at ved at der er to personer der går rundt sammen, opstår der en naturlig måde hvorpå informanten i-tale- 


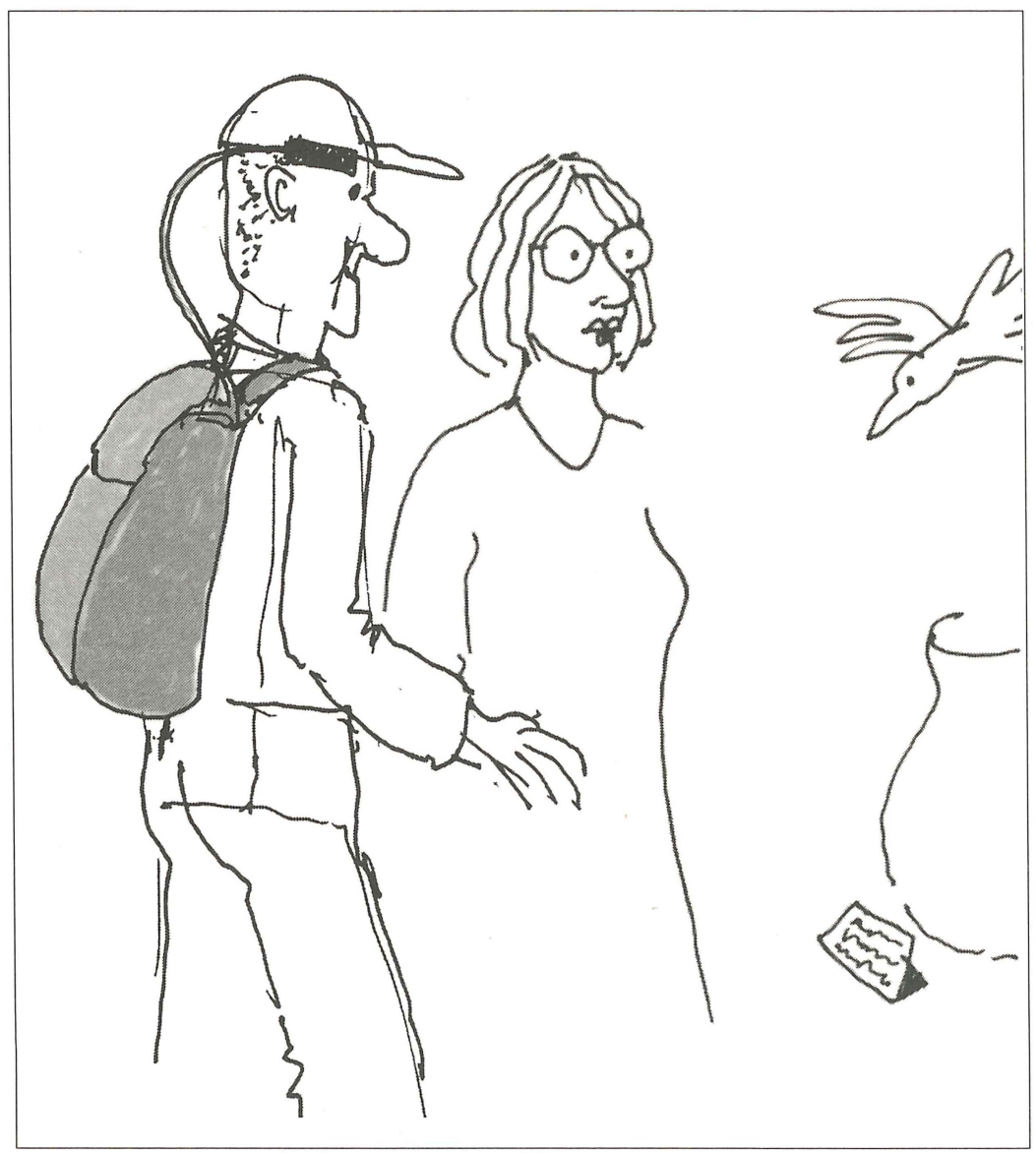

Illustration 1:

Forsogspersonen har en kasket med et lille videokamera på hovedet. På ryggen har han en Fjeldräv med videooptager og stromforsyning. Han optager en vandrings-video samtidig med at han folger med en ven eller veninde.

sætter vandringen rundt i udstillingen. Så hvad der optages på vandrings-videoen er dels billeder af, hvad informanten ser på og det er den samtale de to besøgende har med hinanden under vandringen rundt $\mathrm{i}$ udstillingen.

Man kan sige at hvad der registreres er en naturalistisk vandring som den ville være under almindelige omstændigheder. Selvfølgelig er informanten bevidst om at hun optager, hvad hun ser på og taler om undervejs og der er alle muligheder for, at hun kan vælge at spille roller fx som den "gode museumsbesøgende», men det er jo også interessant hvordan hun konstruerer den rolle.

Projektets empiri indsamles på to måder:

- vandrings-videoen

- interview-video

Hvor vandrings-videoen kan ses som en temmelig uforstyrret vandring så beder jeg informanten efter denne vandring af ca. én times varighed - om at udvælge 3-4 genstande eller områder i udstillingen, 
som har gjort særlig indtryk på hende eller som hun i særlig grad forbinder sig personlig med, eller som kalder på personlige erfaringer hos informanten. Dette interview finder sted ved at jeg går med informanten til de tre udvalgte genstande. Det er formålet med interviewet at informanten i-tale-sætter den oplevelse og de associationer, som hun knytter til de genstande hun har valgt. Her er det forskeren der sætter dagsordenen for, hvad der tales om og spørges om - men det er på informantens betingelser. Interviewet optages på video, men her er det forskeren der har kasketten på hovedet og optager dels informantens ansigtsudtryk og gestik og dels den genstand som der tales om.

De to videoer danner det empiriske grundlag for den analyse som forskeren så må foretage efter besøget.

\section{- OG KØBENHAVNS BYMUSEUM: «UNDER DEMOKRATIETS VINGER»}

Projektet er undervejs. Dvs. at det hele tiden er under udvikling. Projektets metode og teori er løbende til diskussion og det jeg her fremlægger må ses som et udtryk for de muligheder der ligger i projektet og som kan videreudvikles.

Jeg har valgt ét forløb ud for at kunne vise de metodiske og teoretiske problemer projektet medfører. Jeg har valgt at bruge Københavns Bymuseum som udgangspunkt. Her har jeg så indsnævret det til den udstilling som handler om dette århundrede, nemlig Under demokratiets vinger.

Der er flere grunde til at jeg har valgt denne udstilling som det empiriske udgangspunkt. Dels handler den om en periode hvor den besøgende kan genkende dele af tidens begivenheder og genstande og finde dele af sin egen historie. Dels synes jeg at det er en udstilling som har et stort betydningspotentiale. Og dels er det en udstilling der har en klar intention med sin fortælling. ${ }^{5}$

Jeg kan kort beskrive udstillingen. Den er primært opbygget i ét stort rum. Langs ydervæggene er der en frise som primært består af fotografier (og andre billeder) og en række korte tekster. Venstre del af rummet viser den kronologiske tid fra 1900 frem til 1945. Højre side af rummet viser tiden fra 1960-1998. Ud over de flade plancher er der placeret nogle ret få og små genstande som knytter sig til bestemte årstal fx Ellehammers motorcykel og protestsangeren Cæsars guitar.

I midten af rummet er det tre øer i hver side af midten. På venstre side ligger fokus på 1920-40erne og på højre side er det 1960-70erne. De tre øer på hver side handler om tre temaer: kommune og administration; produktion; hjem. Her er det en ophobning af genstande med en række mindre tekster som forsøger at pakke genstandenes historier ud.

Den besøgende får gennem introduktionsteksten præsenteret den overordnede struktur:

I 1909 fik også kvinder og tyende valgret til kommunevalget. Det var jo stadig kun skatteydere der havde stemmeret. Man kunne altså kun stemme, hvis man havde en indtægt over et vist niveau eller havde ejendom. Folkestyret var nu principielt den politiske magthaver.

Udstillingen Under demokratiets vinger belyser epoken ved at fokusere på 1920-30erne og igen 1960-70erne. I hver af disse perioder ser vi på 
160 Bystyret og dets indflydelse, og på indbyggerne og deres hjem og arbejdsplads.

I 1920-30erne var den samfundsstruktur der så dagens lys før 1900, blevet tydelig. Konturen af de nye befolkningsgrupper: lønarbejdere, kapitalejere og den indbyrdes modsætning er blevet tydeligere. Begge parter organiserede sig. Den nye måde at producere på krævede en sund, skolet og veluddannet arbejdskraft. Nye ideer om samfundets struktur: ret til velfærd og pligt til solidaritet slog igennem. Målet og ønsket om en velfærdsstat blev formuleret.

I 1960-70erne ser det ud til at målet er nået. Men samtidig begynder målgruppen - den almindelige københavner at blive mere diffus. Københavneren er ikke mere den samme, som da man satte målet i 1930erne.

Udstillingen gør et kunstgreb ved at skille kommune, produktion og hjem fra hinanden og ved at vælge to tidsperioder ud. Derfor har vi valgt et kronologisk udvalg af københavner-begivenheder og byens topografi langs ydervæggene. Det viser, at delene hænger sammen, og samtidig anslår det tidens gang i København ved at vise de udtryk forskellige tider har afsat i bybilledet.

\section{"UNDER DEMOKRATIETS VINGER» - OG ANNE}

Anne (25) går sammen med sin veninde Rikke (25) i ca. en time rundt i udstillingen. Det umiddelbare indtryk ved gennemsynet at vandrings-videoen er, at de taler meget sammen og er meget engagerede besøgende. De finder genstande, fotografier og oplysninger, som de viser hinanden og kobler til deres egen livsverden.

Når jeg konstruerer en oversigts tegning over deres vandring viser det sig at de bruger dobbelt så lang tid på tidsplancher langs væggene som de bruger på øerne med de mange genstande. De bruger halvanden gang så lang tid på genstande på øerne i 1960-70erne end på genstandene i 1920-30erne og at de ser mange flere genstande i 1960-70erne.

Deres tidsforbrug på de enkelte dele afspejler sig også $i$ at de ser på et større antal fotografier og billeder nemlig 55 og kun ser på 30 genstande.

Man kan sige at de autentiske fotografier kunne ses som ting eller genstande, fordi der er taget fra én brugssammenhæng og bragt ind i en anden på museet og altså er blevet musealiseret. Men det er ikke Annes brug af fotografierne. Hun bruger dem mere som kommunikation og netop i sammenhæng med teksterne bliver billedernes brug forvandlet fra at være genstande, til at være en fortælling i tekst og billeder som en slags ophængt historiebog. Den faglige formidling i billeder og tekst fremstår måske mere sammenhængende og billedernes skjulte historie pakkes nemmere ud af Anne.

Genstandene har også en tekst - men det virker umiddelbart som om de er sværere at pakke ud. Hvad vil de dog fortælle?

Der var nogle spørgsmål jeg umiddelbart var interesseret i:

Hvad sker der under den besøgendes vandring rundt $\mathrm{i}$ udstillingen?

Hvilke fortællinger konstruerede den besøgende?

Hvad tillægger den besøgende særlig betydning?

Hvordan er samspillet i den sociale sammenhæng?

Svaret på disse spørgsmål kan kun fremskaffes gennem en analyse af vandringsvideoen. Det er temmelig indlysende at når Anne og Rikke taler sammen så er det netop i den kontekst at de er sammen og 


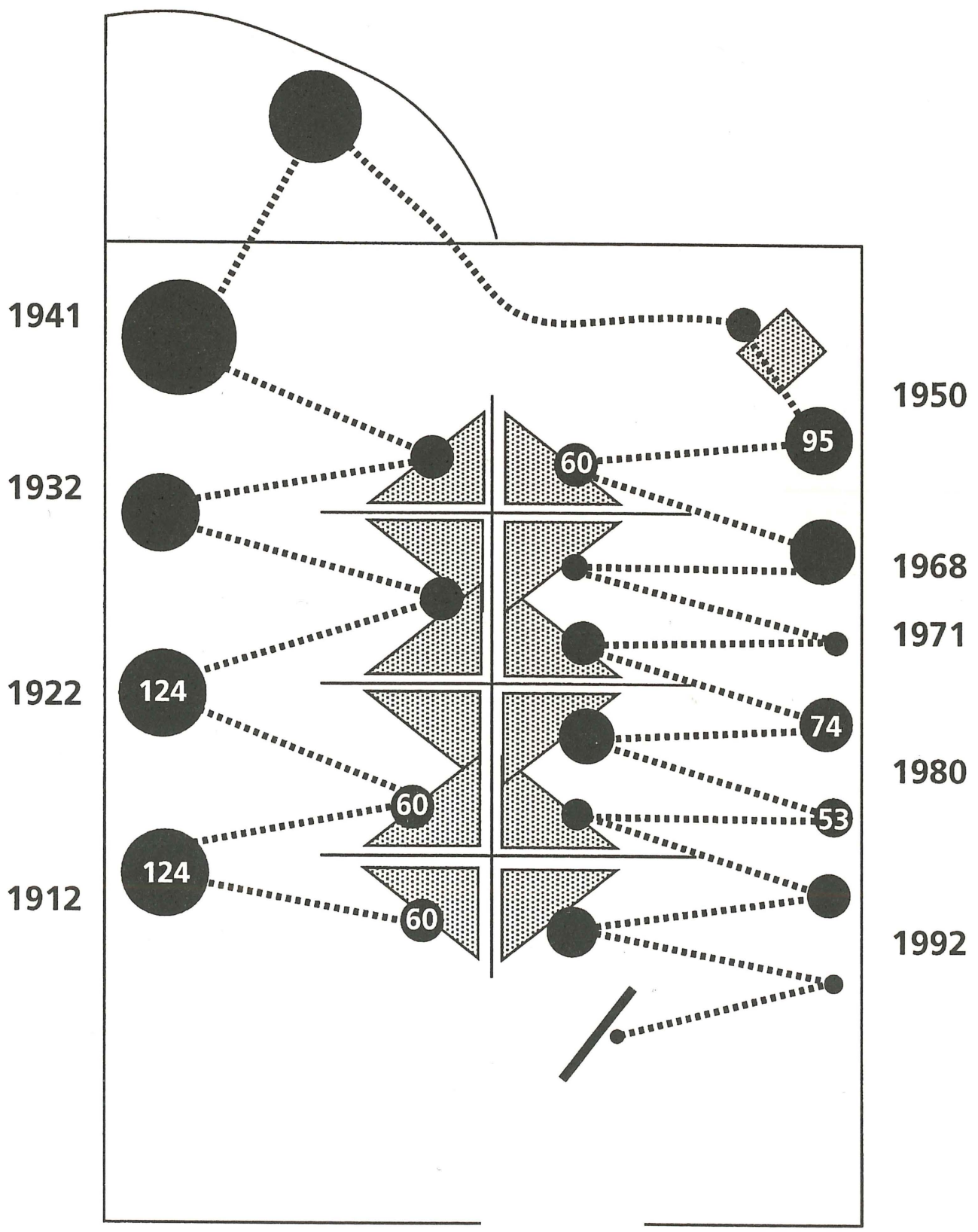

Illustration 2: Plan over udstillingen "Under demokratiets vinger» de sorte cirkler angiver Annes tidsmassig ophold ved enkelte dele $i$ udstillingen. Anne og Rikke bruger dobbelt så lang tid på tidsplancherne som på genstandene. När de kommer til 1973 hvor de selv blev fodt-sä kommer der mange flere bevagelser mellem plancher og genstande. 
162 at de ser på de samme ting. Derfor bliver deres bemærkninger til hinanden også temmelig rudimentære og kan ikke på nogen måde give svaret på min spørgsmål. Det er først gennem en analyse af vandrings-videoen at de rudimentære bemærkninger kan forstås i en sammenhæng.

Jeg vil derfor først vise hvordan de fragmenterede visuelle og verbale ytringer kan kategoriseres og derefter hvordan de kan udsige noget om de læsestrategier som Anne bruger for at skabe betydning i kaos.

Ud fra vandrings-videoen har jeg konstrueret følgende 6 kategorier:

- Videns relationer

- Interne relationer

- Eksterne relationer

- Genkendelse relationer

- Sanse relationer

- Medie relationer

\section{VIDENS RELATIONER}

Anne får noget nyt at vide om noget hun kender: Hun ser et fotograf af juletræet på Rådhuspladsen «Juletræet på Rådhuspladsen startede i 1914" $(22: 40)^{6}$ læser hun op med forundring i stemmen. Hun overraskes over en anden kendt ting for hende [1939] " «Kom Fr. Klokken» (31:15).

Men hun får også noget nyt at vide om ting hun ikke kender på forhånd: Hun ser et fotografi og bliver glad og overrasket [1932] «Stoppenålen - det første trafiklys. Hvor sjovt!» (30:15).

Hun ser protestsangeren Cæsars originale guitar [1965] «Make love not war. Fisse - Cæsar. Alli Balli Be 1965 - nej hvor fedt. Og han blev arresteret [siger hun og kigger op fra guitaren og op på et fotografi på tidsplanchen ovenover]» (42:19). Men det der tænder hendes mest og som overrasker og forarger hende er et humørbarometer [60erne] hvor man kan sætte en pil på sur, vred,... Rikke spørger "Skulle hun sætte den eller han?» Anne: «Nej, hvor grotesk!» (51:10) og her bliver de stånde længe og Rikke fotograferer humørbarometeret.

Det nye er altså både det at få sat et årstal på en begivenhed; at kunne sammenligne noget hun kender med første gang det optræder; at fă en helt ny viden der er helt overraskende for hende. Hun reagerer med spontane bemærkninger om at det er sjovt, fedt, grotesk - men også gennem sit kropssprog og stemme ved at udtrykke forundring og overraskelse.

\section{INTERNE RELATIONER}

Anne får ikke bare noget nyt at vide men ser også sammenhænge mellem noget der er nyt for hende som hun ser på udstillingen og så hvor den samme ting optræder andre steder på udstillingen.

Hun ser først den meget flotte motorcykel [1908] som opfinderen Ellehammer har bygget «Neej, hvor er den sej den cykel. Det er Ellehammer» (21:36) og lidt senere ser hun et fotografi af en gammel flyvemaskine [1912] «Nej. Ellehammer har også bygget flyvemaskiner!» (22:40).

Anne har en meget god visuel hukommelse. Hun ser den første pølsevogn [1921] og undrer sig over at en pølse kostede 25 øre dengang - og langt senere

Illustration 3: Her er tre klip fra Annes vandringsvideo. Ellehammers motorcykel; hans fly og så et kig ud i rummet. De kan give et indtryk af hvordan og hvad Anne optager. 

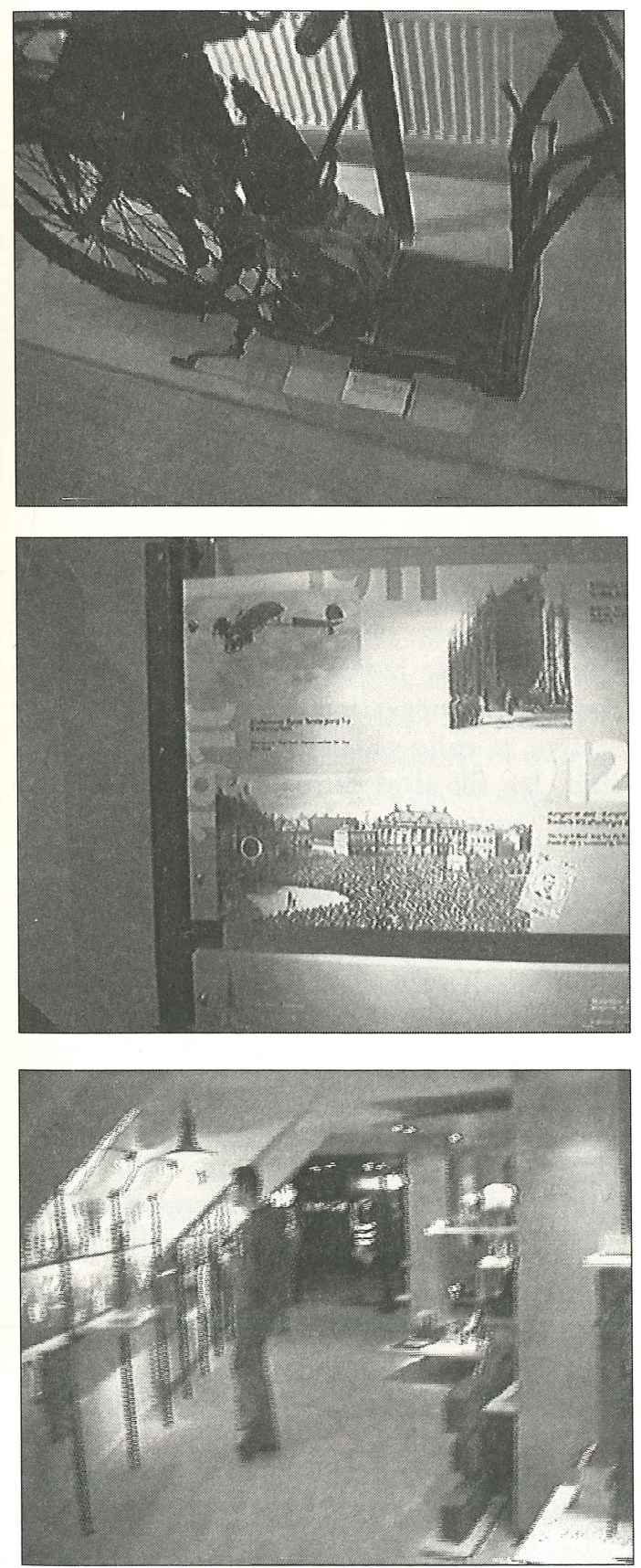

[i 1940erne] ser hun et andet fotografi af en pølsevogn og siger "Pølsevognen har sandelig udviklet sig fra tidligere.» (36:31).

Man kan sige at Anne er en meget opmærksom besøgende. Hun får øje på nogle af de relationer som sikkert er skabt af udstillingens tilrettelægger og hun accepterer dennes vinkel på materialet og tiden.

\section{EKSTERNE RELATIONER}

Anne ser ofte relationer mellem det nye hun ser og så den nutid hun selv lever i.

Det er meget klart da hun ser et luftfotografi af Københavns Lufthavn fra 1925. «Nej, nej, se! Det er lufthavnen. Har du været ude og se den nye? Jeg var derude forleden dag. Jamen det er helt vildt. [her ryster Anne på hovedet for at understrege hvor vigtigt det er hvad hun siger] Det er rigtig fedt. Lækkert. Total stilrent. Poul Kærholm stole. Der er rene linier kan jeg love dig!» (27:54). Rikke stiller spørgsmålstegn ved Anne opfattelse ved at sige at hun har læst nogle anmeldelser og der virker det som om lufthavnen er temmelig rodet. Den indvending får Anne til at forstærke sin egen opfattelse: «Det synes jeg slet ikke.»

Anne fokuserer på sin relation mellem det gamle fotografi, som kommer til at virke som en katalysator for hendes nyligt oplevede besøg på den nye lufthavnsbygning, som dermed helt kommer til at overskygge den historisk nye information.

Anne ser et fotografi fra 40erne som viser Nyhavn. Det vækker erindringen om en meget personlig historie: "Min moster har ikke boet i Danmark i utrolig mange år. For et par år siden flyttede min kusine 
164 til København. Og min moster nægtede hun skulle bo i nærheden af Nyhavn. For hun var overbevist om at det stadigvæk kun var en ludergade.» (35:30).

Som københavner ved Anne godt hvordan Nyhavn har forandret sig til at være et meget mondænt kvarter. Hun demonstrerer det gennem sin historie og ved at markere at det må alle og enhver da vide hvis man altså har boet i Danmark.

\section{GENKENDELSES RELATIONER}

Anne får megen ny viden især gennem fotografier og tekster. Det er her hvor formidlingen er mest eksplicit at det også lykkes for Anne at fange den betydning, der er potentielt tilstede. Der er også et stærkt element af genkendelse - men ofte overskrides denne genkendelse og bliver til udvidelse af hendes oplevelse, viden og erfaring.

Genstandene vækker megen genkendelse. Tingene er noget i sig selv men de kobles af Anne til hendes egne personlige erfaringer. Man kan sige at gennem genstandene pakker hun nogle af sine egne personlige erindringer og oplevelser ud.

I 1930er-øen fra hjemmet ser hun en Nilfisk støvsuger: "Sådan én kan jeg da huske. Sådan en havde min mormor og morfar.» (32:08). Nogle gange kobler hun også nogle sansemæssige oplevelser på genkendelsen. Hun ser er sort telefon med drejeskive fra 60erne: "Åh, sådan en telefon har min mormor og morfar stadigvæk. Og røret er bare så tungt. Det er et fedt rør at have faktisk.» (40:45).

Her i 1960-70erne kommer der mange ting hun genkender. Nogle ting genkendes bare fordi hun har set dem og kan huske dem: "Karoline koen - den kan jeg da huske. Den havde de også da jeg var barn.» (42:10). "De der ski hvad jeg.» (46:25).

Men genkendelsen løfter sig ud over den rene registrering og knytter sig tæt til personlige oplevelser. Hun ser en Pingvin sparebøsse og en bankbog: «Sådan en bankbog der. Jeg kan huske hvor stolt jeg var da jeg var oppe at hæve på min bankbog første gang." (43:20). Men der er to ting der virkelig tænder for erindringen. Det ene er den $\varnothing$ der viser en masse gammelt legetøj. Her bryder Anne og Rikke ud i højre råb: «Nej, nej sådan nogle havde jeg også... madkasse kan man stadig købe." (42:36). Den anden er Carmen Curlers som virkelig vækker minder: «Sådan nogle havde min mor. Er du klar over hvor meget hår jeg har mistet på at prøve at rulle sådan nogle ind i mit eget hår. Jeg fik altid filtret så meget ind at vi blev nødt til at klippe det midt over.» (50:25).

Genstandene virker altså som cues der er med til at Anne i-tale-sætter og dermed husker oplevelser og historier fra hendes eget liv. Ligesom hele udstillingen kan ses som en fortælling om et århundrede og fortæller meget som vi allerede kender - så vækker konglomeraterne Anne's personlige historie til live. De fungerer som anledninger til at huske og genfremkalde erindringer og oplevelser og viden fra Annes personlige liv.

\section{SANSE RELATIONER}

Anne taler i sin vandring ofte om sansemæssige oplevelser. Når hun taler om hendes mormor og morfars sorte telefon - så taler hun om følelsen af det tunge rør. Eller når hun taler om Københavns Lufthavn så 
er det om det smukke og stilrene.

Det æstetisk betyder meget for Anne. Hun er betaget af to store guldbelagte bogstaver BE: "Det ser ud som om det er lavet af kagedej.» (28:45). Hun ser på et farvefotografi af en $s ø$ om natten som spejler lys: "Det er flot når det spejler sig ned i søen.» (34:30). Og hun ser et andet fotografi som viser nogle både ved vintertide på en kanal: «Det billede gad jeg godt have forstørret.» (36:38). Og så taler hun og Rikke længe om hvordan det fotografisk er optaget med lang lukkertid.

Det æstetiske viser sig også $\mathrm{da}$ hun ser en indkøbskurv fra 60erne med madvarer, dåser og vaskesæbe: «De var ikke just indbydende madvarer så ud. Det ser ikke særlig lækkert ud!» (46:25). Anne har en stærkt udviklet fornemmelse for det æstetiske og læser de visuelle udtryk i emballagen og tager stilling til dem som noget der ikke er tillokkende.

Ligesom Anne var meget begejstret for Københavns Lufthavn så kommer hendes interesse for de æstetiske til udtryk i et fortløbende interesse for arkitektur.

Hun ser et fotografi af Politigården [30erne]: «Politigården - er og har altid været meget personlighedsforladt.» $(27: 10) . O g$ denne holdning fortsættes da hun ser fotografiet af SAS Hotellet [1956]: «Så blev der bygget højhuse. Det er så grimt; hvad har de tænkt på? Den der type byggeri er så megagrimt!» (39:46). Og det forholder hun til et fotografi af B\&W: "Den bliver ved med at være pæn. Den bliver aldrig grim. Det er ikke som de andre højhuse vi så før - de bliver så hurtigt grimme!» (45:18). Og det med at arkitektur holder gennem tiden udbygger hun da hun ser Udenrigsministeriet [1980]: «Se der kommer uden- rigsministeriet. Det virker som om det var i går det blev bygget.» (47:40).

Annes æstetiske oplevelser går ud over genkendelsen af tingene. Ting og billeder virker meget provokerende for hende og udvider hendes oplevelse af tingene. Hun aktiverer forskellige følelser og værdier og vurderinger og tager stilling for og imod hvad hun ser.

Det er svært at forholde sig til de konkrete oplysninger som andet end oplysninger. Man kan få noget nyt at vide eller man kan få noget bekræftet som man allerede kender - men det virker ikke særlig provokerende for selv at tage stilling som besøgende. Men Anne medbringer og skaber selv sit eget værdisystem - og det som tænder hende er det æstetiske. Hun bliver måske ikke overrasket men får mulighed for at tydeliggøre sine egne værdier i forhold til tingene.

\section{MEDIE RELATIONER}

Anne finder nemt de mange mediereferencer der er plantet i udstillingen og genkender selvfølgelig Tommy Steele, Beatles, Twiggy, Savage Rose, Røde mor... og selvfølgelig forbinder hun et gadeskilt fra Saxogade: "Var det ikke Sonja fra Saxogade - hun hed?» (29:30). Et fotografi af Hüttemeier fra 1951 får Anne Rikke til at tale om hendes skåneærmer (som man ikke ser på fotografiet) og om hendes alder. Så de regner og regner. Hvis hun nu var 30 i 1951 så...

Den eneste overraskende medierelation kommer da de ser på det store fotografiapparat fra Rådhuspladsen. De ser på kanonfotografens billeder: "Det kunne være lidt flippet hvis ens far eller mor lige pludselig stod her...» Rikke: "Med en anden... Hov 
166 en rigtig dansk søhelt [til et fotografi af en sømand med sin kæreste] Han ligner hvad er det nu han hedder Scherre... er det Martin?» (38:19).

I modsætning til de fleste andre genstande - så er netop pladeomslag og modefotografier og magasiner netop kommunikation på forhånd. De kommunikerer så hurtigt og direkte og giver mest genkendelse.

Man kan se Anne og Rikkes samtale om kanonfotografens billeder og om Hüttemeier som et forsøg på at tilføre det genkendelige noget mere - genkendelsen er ligesom ikke nok. Det er ud fra en vis kedsomhed med kun at genkende tingene at de må opfinde noget, der kan tilføre det mere interesse.

\section{TEORIEN OM DE FIRE LAESESTRATEGIER}

Relationen mellem objekt og læser er meget kompleks og transaktionen medieres af tre forskellige fremtrædelsesformer: 1) æstetisk kvalitet, 2) opmærksomhed og 3) mål. ${ }^{8}$

Den første dimension i relationen mellem læser og objekt er den æstetiske kvalitet. Man kan se det som et forløb mellem genkendelse og udvidelse. Genkendelse beskriver et tilbagefald til tidligere fortolkningsskemaer eller stereotyper når man konfronteres med et objekt, mens udvidelse involverer aktiv reception af objektet sådan at dens kvaliteter kan modificere tidligere dannede vaner eller skemaer. Man kan se genkendelse som en opbremset perception før den har haft mulighed for at udvikle sig frit. Genkendelse er begyndelsen af en perceptionshandling men denne begyndelse tillades ikke at udvikle sig til den fulde perception af den genkendte ting. For at skabe udvidelse må læseren i en skabende proces åbne sig over for en forandring af egne skemaer og egne erfaringer.

Den anden dimension i transaktionen drejer sig om hvordan den psykiske energi bliver kanaliseret. Opmærksomhed er nødvendig for at realisere en psykisk transaktion. Enhver bevidst erfaring ligger på et kontinuum som går fra kedelig ensformighed i den ene ende og til fornøjelig variation i midten, til angstskabende kaos i den anden ende.

Den tredje dimension er målet med transaktionen. Målet kan være underholdning og tidsfordriv. Det kan være oplysning og viden. Det kan være relationer til andre menneskers liv.

Teorien om De fire blikke tager sit udgangspunkt i de tre elementer i transaktionen mellem objekt og læser. Det er en teori om læsestrategier og dermed om hvilke værdier som er vigtige for læseren. Den rummer både det æestetiske og referentielle i forhold til emne, udtryk og indhold: den rummer den personlige relevans og forudviden; den indfanger den konkrete læsers værdier som er flukturerende og at der gennem selve læsehandlingen skiftes mellem forskellige læsestrategier.

Teorien om De fire blikke skal kunne indfange objektet i dets kontekst og i læserens kontekst.

Det låste blik: hvor læseren forventer genkendelse og bekræftelse - jeg ser det som det er tænkt jeg skal se. Det låste blik forbliver inden for læserens velkendte skemaer.

Det åbnende blik: hvor læseren forventer en udvidelse af sine erfaringer og gennem transaktionen lægger vægt på det æstetiske og overraskende. 
Det pragmatiske blik: hvor læseren søger modeller for hvordan hun kan handle i sit eget liv.

Det spejlende blik: hvor læseren forventer at spejle sit eget liv og erfaringer i «de andres» liv og erfaring.

Det er et vigtigt element $\mathrm{i}$ teorien at den konkrete læser bruger to eller flere læsestrategier og at hun løbende skifter mellem dem.

\section{ANNE - OG DE FIRE LAESESTRATEGIER}

På sin vandring gennem hele udstillingen skifter Anne mellem de fire læsestrategier.

Hun bruge Det laste blik og genkender noget der er nyt for hende: At det var i 1912 at der kom juletræ på Rådhuspladsen. Hun genkender og noget som velkendt: hun ser pladeomslag af Tommy Steele, Beatles, Røde mor, Savage Rose, den første gang Den lille Havfrue fik savet sit hoved af... og en utrolig masse andre ting der ikke vækker hendes opmærksomhed ud over at hun genkender objekterne. De er ikke så interessante at de sætter et stort psykisk flow i gang, men kan nærmest ses som grænsende til det kedelige. Hun ser dem på en måde - men ser dem alligevel ikke fordi de ikke rigtig kommer til at betyder noget for hende.

Hun bruger Det åbnende blik og overraskes. Hun ser noget som er kendt og grimt: Indkøbskurven med de ikke just indbydende madvarer. Hun ser noget som er æstetisk smukt: Det herlige fotografi af bådene i kanalen ved vintertide eller lysene i søen. Hun sammenligner arkitektur: De grimme højhuse der bliver stadig grimmere over for $\mathrm{B} \& \mathrm{~W}$ som vedbliver med at være smukt og ser ud som om det er bygget $\mathrm{i}$ dag. Hun overraskes over at huske det sanselige: Hvordan det er at holde det tunge telefonrør som hendes mormor og morfar stadig har. Hun kobler det gamle billede af lufthavnen sammen med hendes nylige oplevelser af den nye Københavns Lufthavn.

Hun overraskes og provokeres også og hun er åben over for de oplevelser og følelser som objekterne fremkalder og de kommer til at betyde noget for hende.

Hun bruger Det pragmatiske blik og finder det som berører hendes daglige liv. Hun forbinder billedet af Nyhavn i 40 erne med historien om hendes mosters opfattelse af Nyhavn som en ludergade. Hun ser Carmen Curlers og husker tydeligt hvordan hun som barn fik filtret sit hår så meget at det måtte klippes af.

Anne forsøger hele tiden at finde relationer mellem objekterne og hende selv. Da hun kommer til årstallet 1973 - så bemærker hun at "her blev jeg født.» Hun finder på en måde tilbage til gamle modeller som hun har levet sit live efter og de kommer til udtryk i en slags nostalgisk tilbageblik.

Hun bruger Det spejlende blik og spejler sit eget liv andres. Hun bliver vildt optaget af Humørbarometeret og af det liv eller den kultur som den udspringer af og får på den måde tydeligt markeret sin afstand til det liv set $\mathrm{i}$ forhold til hendes egne værdier og normer.

Man kan sige at Anne skifter læsestrategi mens hun bevæger sig rundt i udstillingen og at hun over for nogle objekter vælger det Det àbnende blik og over for andre objektet vælger Det pragmatiske blik. Det er til en vis grad rigtigt. Men over for et 
168 og samme objekt kan hun skifte mellem forskellige læsestrategier. Vi kan tage Carmen Curlers som eksempel. Her vælger hun først Det åbnende blik ved at lade sig overraske af at se det hun kender men som hun samtidig ikke nøjes med at konstatere: nå, her er curlers og det var i 70 erne de blev moderne. Hun perciperer dybere og udvidende og kobler det så til Det pragmatiske blik hvor hun forbinder curlers med nogle stærke personlige oplevelser fra sin barndom. Men hun bruger også Det spejlende blik og tager afstand fra selv at bruge den slags curlers i dag. Det var dengang. Det var en anden kultur, en anden generation og et andet liv end det hun fører i dag.

Læsestrategier er altså dynamiske og flukturerende.

\section{ANNES UDSTILLING OG FORTELLING}

Hvilken fortælling skaber Anne? Hun skaber eller genskaber ikke udstillingens fortælling om kommune, arbejdsmarked, hjem og forbrug. Hun har selvfølgelig forstået den grundlæggende struktur i udstillingen fordi hun jo er en grundig læser. Hun anvender i høj grad Det låste blik og forsøger at forstå det som man har tænkt hun skal forstå. Men hun møder udstillingen med sin førviden og værdier. Hun skaber teksten og hun skaber teksten sammen med veninden Rikke. Hun ser en helt anden udstilling end den intenderede.

Ud fra analysen af 6 kategorier og med De fire blikke tegner der sig en besøgende, der er meget optaget af to ting: Anne lægger meget vægt på æstetik og kvalitet i relation til objekterne - og hun lægger stor vægt på at kunne relatere sig person- ligt til objekterne. Det betyder meget for hende at hun kan sætte objekterne i relation til tiden og derfor bliver tidsplancherne vigtige for hende. Det er her hun nogle gange får overraskende viden om billeder og genstande. Hun er også mere optaget af plancherne end af de konkrete autentiske genstande. Ikke at genstande ikke betyder noget - for de indgår samtidig som en del af hendes grundlæggende forventning til et museum - at der skal være genstande. Men det er vigtigere at de er der som en mulighed, end at hun faktisk bruger dem i sin konstruktion af sit besøg i udstillingen.

Anne er åben. Hun er villig til at blive overrasket. Og hvis objekterne ikke i selv er overraskende så er hun god til at finde overraskende måder at forbinde sig til objekterne på.

Anne glider nemt mellem alle fire læsestrategier og er villig til at finde en anden læsestrategi hvis den tidligere ikke rigtig passer. Men det betyder ikke at alt er muligt. Hun udelukker store mængder af mulige oplevelser og viden fordi hun samtidig med sin åbenhed - er lukket. Ved at vægte Det åbnende blik og Det pragmatiske blik leder hun efter noget der kan overraske hende og noget som hun kan forbinde sig personligt til - og hendes værdier er æstetik og kvalitet og en fortælling. Derfor kommer planchevæggen til at betyde meget for hendes oplevelse fordi det er med til at strukturere hendes egen fortælling. Mens hendes værdier om æstetik og kvalitet får hende til at udelukke de talrige andre historier det er muligt at konstruere ud fra udstillingen. Æstetik og kvalitet forbinder hun meget med håndværk og dermed med det sanselige. Det er også gennem det sanselige at hun relaterer sig 
til mange af de objekter som hun selv har oplevelser med fx Carmen Curlers, telefonrøret, legetøj...?

Anne er en utrolig god forsøgsperson. Hun i-tale-sætter i stor udstrækning hvad hun oplever under sin vandring. Hun og Rikke indgår $\mathrm{i}$ en meget fin dialog og hun får både med- og modspil til sin egen itale-sættelse.

\section{DISKUSSION AF METODE OG FORLØBET MED ANNE}

Kan man forestille sig at de erkendelser der produceres kan bruges til at skabe anderledes og måske bedre udstillinger? Hvis vi bruger Anne som en slags modelbesøgende så ser der ud til at være et problem mellem hendes fortælling og udstillingens. Hvis man skal tænke at en udstilling skal kunne skabe muligheder for $D e$ fire blikke - så er den konkrete udstilling $\mathrm{i}$ stand til det fordi Anne er så god en besøgende og læser. Men hun kunne godt få mere hjælp. Hun finder primært bekræftelse på det hun allerede ved - og der er for lidt som er nyt og udfordrende for hende. Hun er god til at forbinde dele af udstillingen med andre dele af udstillingen. Hun er god til at forbinde sine personlige oplevelser med objekterne - men hun får ikke så megen hjælp.

Jeg kunne godt forestille mig at der ved at sammenstille objekter var muligt at tydeliggøre sammenhænge, skabe paralleller og skabe modsætninger. Så på trods af en åbenlys glæde som tidsplancherne giver Anne så er de måske udtryk for et større problem - at det er den eneste måde hvorpå det er muligt for hende at lave en historie.

Metoden med at optage en vandringsvi- deo giver et meget fint empirisk materiale 169 som gør det muligt at rekonstruere den oplevelse og den fortælling som Anne konstruerer undervejs under vandringen.

Hvilken rolle spiller det visuelle for analysen? Videoen giver en klar forankring af hvad Anne taler om og hvad hun samtidig kigger på. Men der ligger også nogle uløste problemer. Når Anne fx står foran en genstand i 30 sekunder uden at sige noget er det så fordi hun læser en tekst? Og hvad sker der egentlig $\mathrm{i}$ hende mens hun gør det? Hvordan kan man analysere videoen som det billeddokument, det også er?

Man kan som hypotese have at hvad Anne i-tale-sætter er hvad der kommer til at betyde noget, selv om hun ser på ting $\mathrm{i}$ lang tid uden at tale om dem. Dvs. at det siger noget om hendes opmærksomhed altså hvor megen psykisk energi som hun lægger i den konkrete genstand.

\section{PERSPEKTIVER}

Jeg har som min erkendelsesinteresse: Hvad og hvordan oplever den besøgende udstillingen på museet - og hvordan skaber den besøgende betydning.

Jeg er altså interesseret $\mathrm{i}$ at finde nogle strukturer for den besøgendes oplevelse. Det er ikke tilfældigt at jeg skrive den besøgende. For mit udgangspunkt er at undersøge den individuelle oplevelse og konstruktion af betydning. Det er intentionen med projektet at lave så mange forløb med så forskellige personer at der tegner sig nogle mønstre. ${ }^{10}$

Jeg har som udgangspunkt valgt netop Københavns Bymuseum fordi det er et lokalhistorisk museum, men også fordi det er landets hovedstads museum.

Jeg vil også bruge Roskilde Museum - 
170 fordi man her har truffet nogle valg som styrker den æstetiske og personlige oplevelse.

Jeg kan også forestille mig projektet udvidet til kunstmuseer fordi her rejser der sig nogle helt andre problemstillinger som jeg ikke har afklaret på nuværende tidspunkt.

Man kan også anvende metoden og teorierne på projekter hvor man har en mere lukket erkendelsesinteresse. Fx at undersøge hvordan en konkret udstilling fungerer i forhold til museets mål med udstillingen, altså en slags effektundersøgelse hvor intentioner, analyse af udstillingen og reception registreret gennem video-vandringer og video-interviews indgår som elementer.

Gennem The Museum Experience Project er det muligt at komme tæt på den konkrete besøgendes reception af en udstilling. Det er kvaliteten ved projektet at det er den enkelte besøgendes konstruktion af udstillingens fortælling der bliver afdækket. Jeg håber at jeg gennem analysen af det kaotiske materiale har vist hvordan der kan skabes mening og betydning som gør empirien brugbar.

\section{SUMMARY \\ Close to individual reading strategies and reception of an exhibition}

If you want to know how the museum visitor experiences the exhibition there is a long tradition of using registration of the visitors' moves in the exhibition to find out where the hot-spots are; or using questionnaires to collect information that can easily be quantified; or using qualitative interviews of the visitor after the museum experience.

The problem with these methods is that the visitor needs to formulate a meaning for his or her experience and in this reconstruction of the visit often adds elements that were not present in the experience itself.

The aim of The Museum Experience Project is to get closer to the real walking-around in the exhibition and to the meaning potential the visitor has a chance of realising.

My interest is: What and how does the visitor experience the exhibition at the museum - and how does the visitor create meaning out of the experience?

These considerations led me to construct an equipment that can be used to register how the visitor walks around in the exhibition and what he or she really looks at, to create an empirical foundation for an analysis of the visitor's values.

I constructed a cap equipped with a very small videocamera. The visitor wears this cap on his head and as the visitor moves his head the videocamera moves too. The visitor also carries a rucksack containing a small videorecorder.

The informant walks around the exhibition with a friend because the museum visit is primarily a social activity. The recorder simultaneously makes a record of the natural speech of the informants as they walk around the exhibition. What is recorded on this 'walk-video' is pictures of what the informant looks at, and the conversation the two visitors have with each other while walking around.

The empirical data for the project is collected in two ways:

- the 'walk-video'

- the interview video

The 'walk-video' can be seen recording a rather undisturbed viewing of the exhibition. This part was followed by the researcher asking the informant to select three objects or areas of the exhibition that were of special interest to her/him personally. This interview is conducted in front of the selected 
objects with the researcher now wearing the videocap. The aim of this interview is to make the informant talk about the experience and the associations connected with the selected objects.

These two video recordings form the empirical foundation for the analysis the researcher can make after the visit.

The selected museum was Københavns Bymuseum - Copenhagen's museum of cultural history, and the selected part of the museum was that concerning this century.

In this paper I analyse the 'walk-video' of Anne and Rikke, two women aged 25. I was struck by the fact that the important objects were observed only half as much as that part of the exhibition that consists of photos and text.

From the analysis of the 'walk-video' I could construct six categories:

- Relation of knowledge

- Internal relations

- External relations

- Relations of recognition

- Sensation relations

- Media relations

These six relations could then be combined into the theory of the four gazes - which are the reading strategies Anne chose. The four gazes comprised in the theory are:

The Locked Gaze where the reader expects recognition and confirmation - I see within my wellknown scheme of things;

The Opening Gaze where the reader expects extension of her experience and in the transaction focuses on the aesthetic and the surprising;

The Pragmatic Gaze where the reader looks for models of how to live her life;

The Reflecting Gaze where the reader's own life and experience are reflected in the life and experience of "the other".

It is important to add that a real reader uses two or more reading strategies and shifts among them.

The factual analysis of the 'walk-video' shows that Anne is not creating the story of the exhibition as planned by the museum curator. Her main values are aesthetic and lie in the quality of the objects she looks at. It is important for her to make personal relations. The objects are not important in themselves and for her the surprising knowledge is in the photos and the related text. She is a very good visitor and she constructs relations within the exhibition and to her own life in a very creative way.

This project is at the beginning of a process. It has shown great potential for creating an empirical material that can be used to reconstruct what and how the visitor experiences the exhibition at the museum - and how the visitor creates meaning. The plan is for the project to continue involving 8-16 informants at the same museum. Later the project will be extended to art galleries.

\section{NOTER}

1. Fish, Stanley: Is there a Text in This Class, Cambridge 1980

2. Taborsky, Edwina: «The discursive object» p. 50-77 in Pearce, Susan (ed.): Objects of Knowledge, London: The Athlone Press 1990.

3. Inge Meldgaard har i sin artikel «Fremtidens museumspædagogik - virkelighedsflugt eller forskningsformidling? Et forsvar for den empiriske publikumsforskning» i Nordisk Museologi 1994/2 p.71-92, lavet en meget fin gennemgang af traditioner inden for den empiriske publikumsforskning.

4. Se Ingemann (1998).

5. Marlene Kløver Dreyer har på Kommunikation lavet et projekt om denne udstilling: Museets fortallinger - en semiotisk analyse af en udstilling, Ruc 1996, 36 sider + bilag. 
172 6. (22:40) er en henvisning på det sted på videobåndet hvor dette udsagn og fotografi er placeret. Det kan ses som en kildehenvisning.

7. [1939] er blot en måde hvorpå jeg markerer den enkelte genstand eller fotografis placering i tid.

8. Teorien om De fire blikke er detaljeret udviklet i Ingemann (1996) og (1998). FATAMORGANA. Pressefotografiets virkelighed og lasernes, er et empirisk eksperimentelt receptionsprojekt hvor teorien om læsestrategier er brugt som grundlag for analyser af 16 informanters læsning af forskellige varianter af fire avisartikler. En række of de teorier og metoder jeg har udviklet her har dannet udgangspunkt for The Museum Experience Project.

9. Her kan den opmærksomme læser undre sig. Hvorfor hører vi ikke noget om interviewet om det tre udvalgte genstand? Det skyldes at den idé først er kommet senere. Jeg skriver altså om et projekt i udvikling. Jeg fik Anne til at skrive hvilke tre genstande der gjorde mest indtryk på hende og det var: Model af viserne på Københavns Rådhus (som udstråler kvalitet og håndværk som ikke ses i dag); Irma ur (som viser kvalitet og rendyrket markedsføring der spiller på traditioner); Curlers (fordi det minder om barndommen når hun ville være lige så smuk som sin mor). Ud af 12 personer var der ingen der valgte de samme tre genstande.

10. Det er min erfaring at antallet af nødvendige forløb ligger mellem 8 og 16 forskellige informanter.

\section{LITTERATUR}

Falk, John H. \& Dierking, Lynn D.: The Museum Experience, Washington: Whalsesback Books 1992.

Fish, Stanley: Is there a Text in This Class, Cambridge 1980.
Ingemann, Bruno: Fotografiet under pres. Mellem realisme og konstruktion. Roskilde UniversitetsForslag 1996.

Ingemann, Bruno: FATAMORGANA.

Pressefotografiets virkelighed og lasernes, København: Museum Tusculanum 1998.

Meldgaard, Inge: «Fremtidens museumspædagogik - virkelighedsflugt eller forskningsformidling? Et forsvar for den empiriske publikumsforskning» in Nordisk Museologi 1994/2 p.71-92.

Taborsky, Edwina: "The discursive object» p. 50-77 in Pearce, Susan (ed.): Objects of Knowledge, London: The Athlone Press 1990.

Bruno Ingemann är lektor ph.d. i visuel kommunikation vid Roskilde Universitetscenter, Institut for Kommunikation.

Adr: Roskilde Universitetscenter, Institut for

Kommunikation og Datalogi, P.O.Box 260, DK-4000 Roskilde, Danmark.

E-mail:bruno@ruc.dk 